\title{
How Does Hainan Realize Sustainable Tourism? -- Based on Governance in Environmental Protection
}

\author{
Jue Wang \\ Tourism Department, Hainan TV\& Radio University, Haikou, Hainan, China
}

826794242@qq.com

\begin{abstract}
Hainan government had focused on sustainable tourism development by governance in environmental protection. However, phenomenon that Hainan officials paid much attention to economic growth while they ignored environmental protection is still common, which has a negative impact on sustainable development of Hainan tourism industry. The article focuses on the threats to sustainable development of Hainan tourism industry, the governance in environmental protection, etc. Furthermore, we conclude that effective intervention of Hainan Government is crucial to Hainan sustainable tourism based on environmental protection, especially, effective governance in environmental protection. Hainan may realize sustainable development of tourism industry by governance in environmental protection, such as, building, adapting and innovating "green" institution, strengthening regulation and promoting the reform of property right system.
\end{abstract}

Keywords: sustainable development; tourism industry; governance in environmental protection

\section{Introduction}

Hainan has unique natural tropical tourism resources; Hainan is highly praised by many tourists of being an unpolluted tourist resort in today's world. Unfortunately, pollution of tourism ecological environment and the waste of resources are the externality caused by Hainan tourism enterprises. Most seriously, government's performance was measured by GDP, so sometimes it ignored the social ecological benefits, which severely restricted the development of sustainable development of Hainan tourism industry. Without doubt, the most important responsibility for Hainan government is to protect eco-environment of tourism.

How did ineffective government intervention and negative behavior threat Hainan sustainable tourism? How to eliminate the threats to the Hainan tourism sustainable development? Realization of Hainan's tourism sustainable development based on governance in environmental protection is the main topic of this research.

\section{The Threats to Sustainable Development of Hainan Tourism Industry}

Hainan had constructed Ecological Province for several years. Admittedly, Hainan government had focused on sustainable tourism development under governance in environmental protection. For example, Hainan began to develop market-oriented, low-carbon and high-quality tourism real estate, etc. Hainan will also apprise the leading cadres' performance based on environmental protection. Hence, eco-auditing, Green GDP, etc. will play an important role in Hainan ecological environmental protection and tourism. However, phenomenon that Hainan officials paid much attention to economic growth while they ignored environmental protection is still common, which has a negative impact on sustainable development of Hainan tourism industry, even the whole economic and social development. In essence, tourism sustainable development is under the harmonious condition of tourism resources development and ecological environment protection.

\subsection{Market Failure in Environmental Context.}

Market failure occurs when the free market fails to allocated resources in an optimum and efficient manner. Market failure is the main source of environmental degradation; moreover, environmental degradation is fatal to sustainable development of Hainan's Tourism Industry. Some market failure in environmental context is caused by externality. 
On the one hand, market failure in environmental context is caused by externality, which leads to unsustainable development of Hainan's tourism industry. Even so, the destroyer and the polluter do not have to pay any of these costs as it makes and sells its products, and the price its customers pay doesn't accommodate these costs. (Drogus and Orvis, p162.)

On the other hand, market failure in environmental context is resulted from consuming public goods. Hainan Dong Zhaigang Mangrove Wetlands can be taken as an example. Hainan Dong Zhaigang Mangrove Wetlands is a national nature reserve, and is in The Ramsar List of Wetlands of International Importance. Hence, it is a valuable tourism natural resource of Hainan. However, there were so many free-riders, who raised shrimp or duck there, leading to environmental damage, and poor quality or excessive use of public goods. In addition to reclaiming land from the sea and deforestation about $120 \mathrm{hm}^{2}$, the remaining $157120 \mathrm{hm}^{2}$ of Dong Zhaigang natural mangrove was destroyed by the aquaculture. Eventually, it may result in the Tragedy of the Commons.

\subsection{Inefficient Government Intervention in Environmental Context.}

When there are "market failures", it is necessary for government to intervene. Government intervention does not necessarily imply "optimal" outcomes. Sometimes there is a large deviation between the actual results and the expected target (Chang, 1999, p.195), which means inefficient government intervention, even government failure.

First, the government role of "rational economic man" on the environmental problems may result in "government failure". Government officials and government organizations engage in political activity is to pursue self-interest maximization, such as job promotion and reputation, salary and benefits, and so on. [9] Sometimes, the government is eager to find new economic growth points to realize economic growth and expansion of employment. However, these new growth points may not comply with the basic principles of sustainable development.

Second, the incorrect policy is a kind of inefficient government intervention. Combined with case of Hainan mangrove, its reclamation is caused by the agricultural policy of "taking grain as the key link". In fact, this agricultural policy caused a large area of deforestation, and reclamation of lake and sea for cultivation of agricultural products. In pursuit of agricultural high yield, chemical fertilizer is increasingly used. Admittedly, the incorrect policy is harmful to environment.

Third, government believes in GDP Supremacy which unavoidably results in blind and excessive tourism development. For example, a leader of a county in Hainan declared that the county would build 10 Golf Court. Many international environmental organizations criticized golf courts for occupation of arable land, water consumption, environmental pollution, the abuse of resources, and insisted that it would lead to excessive public expenditure and do harm to Hainan ecological environment and Hainan sustainable tourism industry. This government activity causes a more inefficient allocation of goods and resources than would occur without that intervention [10].

\section{Current Governance to Eliminate the Threats}

To maintain sound and sustainable development of Hainan's Tourism Industry, Hainan government shows concerns for the "threats" and takes measures to protect Hainan's environment.

\subsection{Advocating the State-Centric Governance.}

The state-centric governance model has many features which we associate with effective governance, such as a strong, insulated center combined with institutionalized systems of exchange with the external environment of the state. (Pierre and Peters, 2005. P.36)

First, effective government lays a good foundation for a beneficial interaction between government and society. In this model, government is not able to make decisions entirely on its own and some form of negotiation is required and that is intended to align policies with both particular social interests and the collective concerns of society, as interpreted by the institutions of the state. (Pierre and Peters, 2005. P.30) In fact, during the period of sustainable tourism development, Hainan government showed more concerns for public interest. 
For example, in 2010, Changjiang County Government of Hainan drafted Qizi BayTourist Resort General Plan, in order to avoid its adverse effects on the environment due to the implementation and construction, the government commissioned environmental sciences institute of Sun Yat-sen University to carry out environmental impact assessments. In order to solicit public views and implement the Interim Measures of Public Participation in Environmental Impact Assessment (EIA). Changjiang Government disclosed the Environmental Impact Report of the Plan to the public. And then, the public can question or suggest to the units of planning and EIA during the period of public disclosure. In 2011, Hainan Wanning City Government proclaimed the environmental impact assessments of Xinglong Tourist Resort General Plan; Hainan Government proclaimed the environmental impact assessments of Provincial Tourist Road General Plan. Therefore, as Pierre and Peters (2005) said, social interests have a legitimate right to participate and to have their ideas considered by the state (p.30) in this model.

Second, "Green Accountability", ecological environmental protection accountability, is crucial to sustainable tourism in Hainan. Pierre and Peters thinks that elected official will be held to account gives them considerable clout in fending off political pressures from interest groups. (p.35) In fact, fending off political pressures from interest groups is one of reasons why Hainan government starts "Green Accountability". As mentioned above, the government's role of "rational economic man" on the environmental problems has resulted in "government failure"; government believes in GDP Supremacy. These actions which restrict sustainable development of Hainan tourism are queried by the public and other interest groups, such as a NGO, Greenpeace. Under the pressure of public opinion, one of important functions of Hainan government is to coopt interest groups into the policy process and is likely to enjoy support from the rank-and-file membership of those organizations, (p.35) so Hainan government can put mentioned-above public disclosure into effect. In fact, "Green Accountability" is an important way to eliminate the public queries.

In fact, local government paid much attention to it. For example, intensifying the construction of coastal protective forest, Wanning Government established "Green Accountability" to make responsible leader accountable in 2007; Opinions on Propelling Construction of Hainan as an International Tourism Destination stressed that Hainan should improve responsibility and accountability of the ecological environmental protection, include the comprehensive evaluation system of ecological environmental protection into economic and social development, as well as into comprehensive evaluation system for leading cadres; in 2012, Hainan Government issued the "Twelve-Five" plan, including goals and tasks of energy-saving and emission reduction to promote the construction of international tourism destination, as well as strict accountability and "one-vote veto" institution for ecological protection. Furthermore, in its "Thirteen-Five" plan, Hainan will take many measures to maintain the domestic first-class ecological environment quality. According to the Bulletin of Environment in Hainan Province in recent years, its ecological environmental quality continues to be advanced in the country and air quality is excellent every day.

\subsection{Effective Government Intervention.}

The government should intervene either to limit the extent of such pollution or to make the producers and consumers of the product bear its cost in market failure, as well as enterprises and individuals' behavior. (Drogus and Orvis, p.162)

First, Chang states when there are "market failures", it is necessary for a state to intervene (Chang, 1999, p.186). For example, to eliminate negative externality, Sanya Government banned Sanya Hongsha Seafood Stalls in 2008. Lin Hongmin(2008) said, eutrophication of sea water would be gradually eliminated in its natural purification process with a ban on Hongsha's operation. As expected, Sanya's marine water was the first class in its offshore area in 2010.

Second, Olson posited that one way to overcome this problem is to impose constrains on their members by government. For example, to avoid the Tragedy of the Common, Hainan government has forbidden duck breeding in Hainan Dong Zhaigang Mangrove Wetlands since 2010. What is more, Hainan Land \& Environment Resources Office increased punishment on damaging mangrove wetlands. They promulgated "if environmental sectors find construction project damage mangrove 
wetlands and eroded mangrove wetlands, they will fine the owners 5\% construction project investment for punishment and punish them to replant the same number and area of mangrove wetlands". Such sanctions do work. For example, mangrove trees have increased about more than 1000 acres in Dongzhaigang National Nature Reserve and those which were destructed in the last century are being gradually restored.

\section{Recommendations and Conclusion}

In fact, effective intervention of Hainan Government is crucial to Hainan sustainable tourism based on environmental protection, especially, effective institution building. Chang (1999) said, there are many relatively simple institutional changes that can reduce various costs associated with state intervention (p.199), so institution building maybe is an important function of the developmental state. In fact, government plays a crucial role in institution building (p.195) to prevent and punish the activities of environmental violation and unsustainable tourism.

\subsection{Building, Adapting and Innovating "Green" Institution.}

Building, adapting and innovating "green" institution, such as green fiscal and financial institution, is the key to sustainable tourism. For example, "green" fiscal institution may use subsidies, reward incentives and other initiatives to promote tourism enterprise' energy saving technology, to subsidize tourism enterprises with low pollution and high resource utilization rate; linking environmental protection to financial and credit policy, green financial institution may use mechanism of "Environmental Protection Credit Management".

Hainan can learn some experiences from Shanghai. Since 2006, enterprise's information about environmental violation had been incorporated into the enterprise credit information system in Shanghai. Sharing information between environmental protection departments and financial organizations, "major polluter", who was included in the "pollution blacklist", would be questioned or even banned while applying for credit loans. Being efforts to increase reward or punishments, Green fiscal and financial institution maybe can change tourism enterprises' passive activity of pollution treatment into active behavior.

What is more, establishing and perfecting the taxation system is a key consideration to the resource-saving and environmental protection. On the one hand, to enhance the government's ability to control environmental pollution as well as raise tax revenue, government can bring about some policies, such as, changing tourism operators' sewage charges into emission taxes, raising resource tax rates, levying environment tax or ecological environment compensation on tourists and operators; on the other hand, tax breaks can only benefit tourism operators for environmental protection and those who introduce foreign capital and advanced technology for sustainable tourism.

\subsection{Strengthening Regulation.}

Strengthening regulation to avoid the Tragedy of the Commons and other environmental issues does good to eliminate market failure. Therefore, levying eco-compensation fee, such as travel rubbish treatment fees, tour bus gas pollution and hydropower resource consumption fees, etc., from tourists and enterprises who destruct eco-environment maybe important for Hainan tourism, i.e. they should be charged for emissions of waste, such as waste water, garbage, etc., in accordance with the principle of "polluters pay" and "compensation for damaging environment".

\subsection{Promoting the Reform of Property Right System.}

It will benefit tourism resources utilization and make tourism resources price be reasonable. Lacking supervision and unclear resource ownership results in "Tragedy of the Commons" of tourist scenic spot. No doubt public resources are easily to be used excessively, inefficiently and even be wasted. Hence, reforming property right system of tourism scenic spot explicit ownership of exploitation and utilization right for the tourism resources, the right of ownership and management may lead to optimal mobilization of tourism resources, avoid waste and even eliminate "Tragedy of the Commons". 
As Posner, famous for the Theory of Property Right, said that unowned resources are prone to be used and wasted uncontrollably, but the ownership of property rights can make all of resources effectively utilized; domestic and foreign practices show that public goods provided only by government or by market would result in insufficient supply, so providing public goods by combination of government and market may be an inevitable choice. Therefore, in line with the market economy principles, separation of ownership and operation rights of tourism scenic spot or other quasi-public resources may make resources effectively utilized and avoid "Tragedy of the Commons" to some degree.

Undoubtedly, according to Chang, institution building plays a more direct role in ecological protection, which plays an important role in Hainan's sustainable development. In the short term, the number of tourists and tourism income may fall to a certain extent, due to a ban on featured seafood stalls from operating, levying environment tax or ecological environment compensation on tourists and operators, etc. However, it does well to Hainan's sustainable tourism, because ecological soundness is the biggest competitive advantage of Hainan tourism.

Therefore, to establish good interaction between sustainable tourism and ecological protection, Hainan government attaches much importance to ecological environment. However, there were still some abnormal phenomena, such as, openly violating the law by some enterprises, absence of government regulation, which meant ineffective governance. In fact, the strict system of eco-environmental protection requires strong executive power and effective government intervention.

Integration ecological environment as natural tourism resources into the context of the government's public administration may decrease market failure and inefficient government intervention to some degree; it may make market properly reflect degree of tourism resource scarcity and price tourism resources appropriately; it may create a new environmental protection mechanism with combination of government and market.

\section{References}

[1] Yan, Deng, Pei and Wei, Liu. "Institution Analysis of the Wetlands Degradation". Ecological Economy. Vol.5 (2006) No.3, p. 149-151.

[2] Yu, Wang, and Li, Li, Fan "Analysis of Equality of Public Environmental Service and Regional Disparity". Proceedings on International Conference on Public Administration 2013 (9th). Cape Town, South Africa, Oct. 31-Nov.2.

[3] Wu, Wenzhi. "A Study on the Government Regulation Course in China's Public Scenic Areas and Its Problems", Tourism Tribune, Vol.22 (2007) No.11, p. 37-40.

[4] Juxiang, Liu. "On Scenic Spots Management". Shandong Economy. Vol.144 (2008), No.1, p.135-138.

[5] Ha-Joon Chang. The Developmental State. New York: Cornell University Press. 1999.

[6] Pierre Jon and B.Guy Peters. Governance, Politics and the State. London: Palgrave Macmillan. 2000.

[7] Pierre Jon and B. Guy Peters. Governing Complex Societies: Trajectories and Scenarios. Gordonsville: Palgrave USA. 2005.

[8] Carol Ann Drogus and Stephen Orvis. Introducing Comparative Politics: Concepts and Cases in Context (2nd edition). Washington D.C.: CQ Press. 2011.

[9] Information on: http://www.microsofttranslator.com/bv.aspx ?from=\&to=zh-CHS\&a=http\%3 A\%2F\%2Fwww.studa.net\%2Fhuanjing\%2F110811\%2F08561220.htm

[10] Information on: http://en.wikipedia.org/wiki/Government failure 